\title{
The Indonesian Throughflow and its Impact on Biogeochemistry in the Indonesian Seas
}

\author{
Edwards Taufiqurrahman ${ }^{1, *}$, A'an J. Wahyudi $^{1}$, and Yukio Masumoto ${ }^{2,3}$ \\ ${ }^{1}$ Research Center for Oceanography, Indonesian Institute of Sciences. Pasir Putih 1, Ancol Timur, Jakarta 14430, Indonesia \\ ${ }^{2}$ Department of Earth and Planetary Science, Graduate School of Science, The University of Tokyo, Hongo, Bunkyo-ku, Tokyo 113-0033, \\ Japan \\ ${ }^{3}$ Application Laboratory, Japan Agency for Marine-Earth Science and Technology, Showa-machi, Kanazawa-ku, Yokohama, Kanagawa \\ 236-0001, Japan \\ *Corresponding author: edwa006@lipi.go.id
}

\author{
KEYWORDS \\ Indonesian Seas \\ Indonesian Throughflow \\ Marine biogeochemistry \\ Nutrient flux
}

\begin{abstract}
It has been widely known that the Indonesian Throughflow (ITF) is an important inter-ocean connection with unique and complex oceanographic and geographic conditions, as well as a strong relation to both regional and global ocean currents and climate systems. Many studies on characteristics, mechanisms, and impacts of the ITF have been conducted, mainly focusing on the ITF pathways, transport, water mass mixing processes, and their variability in connection with monsoons and climate systems. In this paper, we summarize some of the critical aspects related to ocean conditions within the Indonesian Seas and the Indonesian Throughflow, with the main focus on studies of marine biogeochemistry in a region affected by the ITF. Although the biogeochemical cycle is one of the key research topics that are needed to advance our ocean understanding, studies on marine biogeochemistry within the Indonesian Seas are quite limited due to less observed data compared to the physical parameters. Further studies on biogeochemistry and efforts to conduct in situ and remotely sensed observations in this region are strongly required. Here, we propose several biogeochemical observations correlated to the ITF.
\end{abstract}

(c) The Author(s) 2020. This article is distributed under a Creative Commons Attribution-ShareAlike 4.0 International license.

\section{INTRODUCTION}

The Indonesian Seas have a complex oceanographic profile as they are part of the Pacific and Indian Oceans, as well as the Pacific and Indian Ocean boundary. This unique region is affected by intricate geological and geographical conditions, such as straddling on the equator and consists of many smaller seas and straits divided by a large number of islands with various sizes (Wyrtki 1961). The water in the Indonesian Seas mainly originate from the Pacific Ocean from two directions: water that comes directly from the Pacific Ocean through the passages in the northeastern regions filling the eastern Indonesian seas, and warmer water from the South China Sea filling the Karimata Strait and Java Sea (Wyrtki 1961). These waters eventually flow out mostly through the southern passages, making up continuous flows with swift currents and a large transport from the Pacific to the Indian Ocean known as the Indonesian Throughflow (ITF) (Figure 1). The ITF coming out of the Indonesian Seas flows westward across the Indian Ocean to eastern Africa, the majority of which then turns southward as the Agulhas current. The ITF also flows southward directly along the western coast of Australia as the Leeuwin current (Talley and Sprintall 2005; Mayer et al. 2010; Sprintall et al. 2014; Feng et al. 2018).

As the ITF flows within the Indonesian Seas, its water mass properties change significantly. The warm and relatively salty characteristics of the Pacific water tend to vanish due to strong vertical tidal mixing (Koch-Larrouy et al. 2007), and/or sill-induced turbulent mixing (Van Bennekom 1988). The mixing is believed to affect the carbon, oxygen, and nutrient (nitrate, phosphates) concentrations in the eastern Indonesian Seas and subsequently in the Indian Ocean (Talley and Sprintall 2005; Ayers et al. 2014).

The Indonesian Throughflow is the only oceanconnector pathway in the equator (Sprintall et al. 2014), and it has an important purpose in the transport of mass and heat from the Pacific into the Indian Ocean (Feng et al. 2018). Numerical model experiments confirmed that, when ITF is intentionally closed, the tropical Pacific tends to have warmer sea surface temperatures and larger upper ocean heat content, while cooler sea surface temperatures (SST) occur in the southern part of the Indian Ocean (Hirst et al. 1993; Godfrey 1996). Moreover, closing the ITF can affect regions far from the Indonesian Seas, such as reducing the strength of the Indian Ocean's South Equatorial Current and the Agulhas Current, enhancing the Pacific East Australian Current, inducing a warmer eastern equatorial Pacific, and even enhancing El Niño Southern Oscillation (ENSO) variability (Song et al. 2007). The ITF, therefore, affects the global ocean circulation known as the Global Conveyor Belt (Koch-Larrouy et al. 2008), as well.

All these aspects of the ITF have attracted the attention of a large number of scientists. To understand the variabil- 


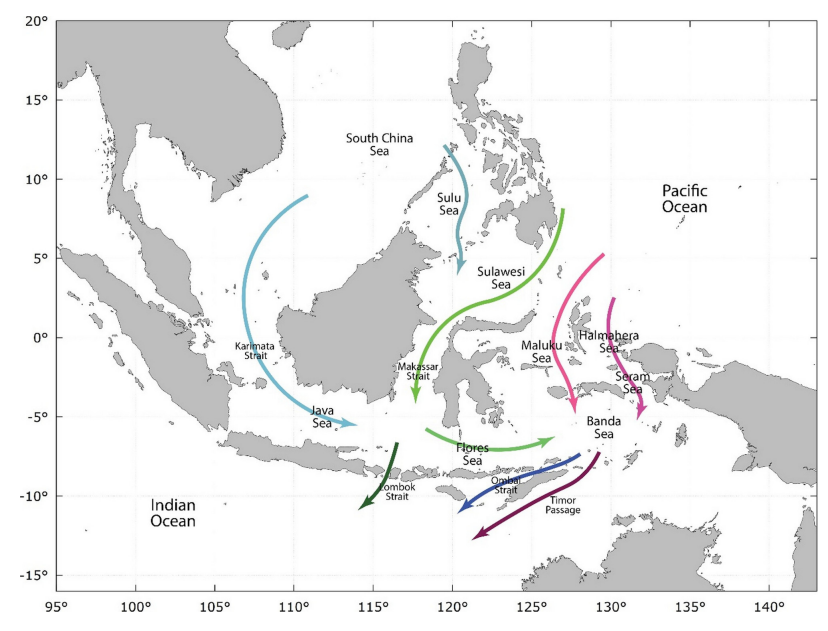

FIGURE 1. The Indonesian Throughflow consists of several currents, all bringing the Pacific Ocean waters to the Indian Ocean. The main input is through the Makassar Strait, Halmahera Sea, and Maluku sea. Input flow from the South China Sea is also confirmed, flowing through the Sulu Sea and Java Sea. The ITF then flows out to the Indian Ocean from the Lombok Strait, or from the Ombai Strait and Timor Passage after the waters mix in the Banda Sea.

ity of a global climate system, for example, one should look into regional changes in the ITF area. Therefore, observation of long term changes in the water mass characteristics and transport of the ITF is crucial to understanding and predicting the climate system, including the regional system over Indonesia (Sprintall et al. 2019).

Several research expeditions have been conducted to observe the ITF, with the main idea of observing the ITF variability to understand its causes and impacts. One of the significant and successful studies is the International $\mathrm{Nu}-$ santara Stratification and Transport (INSTANT) program, which took place in 2004-2006. It was a multinational research expedition that aimed to investigate the properties of the ITF in its main in-and-out flow passages (Sprintall et al. 2004; Gordon 2005). There are also other expeditions conducted by international or Indonesian researchers, such as the "Ekspedisi Widya Nusantara" (EWIN) programs (Horhoruw et al. 2015; Yuan et al. 2018). In addition to these direct observational studies, numerical modeling (e.g. Schiller et al. 1998; Sasaki et al. 2018) and proxybased (e.g. satellite data, tide gauges, corals) research (Gordon 2005; Iskandar 2005; Potemra 2005; Mayer et al. 2010; Murty et al. 2018) have also been conducted. Furthermore, there was also the Infrastructure Development of Space Oceanography (INDESO) project developed for the Government of Indonesia in an attempt to build an accurate monitoring and forecasting ocean system by using the physical and biogeochemical coupled models (Nugroho et al. 2018).

Most of these studies focus mainly on physical aspects of the ITF, such as mean conditions of currents, volume transport associated with the ITF, and their periodical variability. In contrast, there is only a small amount of research aimed at biogeochemical conditions inside the Indonesian Seas and the Indian Ocean related to the ITF variability (Ayers et al. 2014). This review aims to provide an overview of the progress of research on the ITF, in particular on the ITF dynamics and its physical aspects as well as their impacts on biogeochemical aspects of the surrounding waters. Some discussions on biological pump processes, especially in the upwelling area, are included. We also try to show some gaps in ITF research, so that scientists can see opportunities for future research programs.

\section{THE INDONESIAN THROUGHFLOW PATHWAY}

Trade winds over the tropical oceans drive the surface water in the ocean from east to west, raising the sea level on the western side and lowering it on the eastern side. Consequently, the sea level difference and pressure gradient between the Pacific and Indian Oceans appears, with lower sea level and pressure in the eastern Indian Ocean compared with the western Pacific Ocean (Wyrtki 1961, 1987). It was hypothesized that this pressure gradient drives the ITF in the Indonesian Seas that connects the two oceans and influences the transport volume. Yet a recent model suggested the ITF is actually an extension of the Pacific's tropical current systems, including the Western Boundary Current (Mayer et al. 2010).

There are three ITF inflow gateways, bringing in different types of water mass into the Indonesian Seas (Figure 1). The first gateway is for the North Pacific Subtropical Water and North Pacific Intermediate Water, which originate from the North Equatorial Current system of the Pacific Ocean that forms the Mindanao Current. These waters flow into the Sulawesi Sea and then continue to the Makassar Strait (Mayer et al. 2010). The Makassar Strait can only pass surface-to-upper thermocline water because of the shallow Dewakang sill (Talley and Sprintall 2005), but about $80 \%$ of the ITF transport actually flows through this strait (Gordon et al. 2010). South of the Makassar Strait near the Dewakang sill, the flow bifurcates into two parts; one part flows into the Lombok Strait and the other into the Banda Sea (Talley and Sprintall 2005; Koch-Larrouy et al. 2007; Mayer et al. 2010). Outflow via the Lombok Strait enters the Indian Ocean, and the water mass of this outflow is known as the Indonesia Throughflow Water (ITW), characterized by low salinity upper thermocline water (Talley and Sprintall 2005).

The second inflow gate is the Halmahera Sea for the South Pacific Subthermocline Water, and the third gate is the Maluku Sea for the upper thermocline South Pacific Subtropical Water (Mayer et al. 2010). The water passing through these two gates originates from those in the southern Pacific Ocean, which are known as South Pacific Subthermocline Water and South Pacific Subtropical Water. These waters flow into the Banda Sea, into which the throughflow water from the first gateway also flows. The Banda Sea, therefore, can be considered a "mixing place" of the water masses in the three pathways of the ITF inflow.

From the Banda sea, the flow goes through the Timor and Ombai Straits out to the Indian Ocean. Sills in the Ombai and Timor Straits are deep enough to allow the outflow to occupy the water column from the surface to the lower thermocline. The surface water meets the water from the Lombok Strait and joins the ITW. The intermediate water forms the Banda Sea Intermediate Water or the Indonesia Intermediate Water (IIW). Both the IIW and ITW flow into the Indian Ocean, joining the South Equatorial Current in the Indian Ocean (Talley and Sprintall 2005).

ITF measurements have been conducted in the Makassar Strait, from 1996 to 1998. An analysis of mooring observations by Gordon et al. (1999) found that the average transport of water mass in the Makassar Strait is about 9.3 Sv. The dominant component of transport variability is in the annual cycle, with the maximum in June and minimum in December. Water mass transport variability correlates with ENSO variability, with the correlation coefficient of 0.7 (Gordon et al. 1999). More comprehensive measurements were carried out in 2004-2006 under the INSTANT pro- 
gram (Sprintall et al. 2004; Gordon et al. 2010). Results from this observation show that the ITF outflow transport to the Indian Ocean reaches about $15 \mathrm{~Sv}$, while the inflow transport is about $13 \mathrm{~Sv}$ (Table 1). The difference between the inflow and outflow transport value is attributed to extrapolation uncertainty and/or unresolved surface layer transport in the Lifamatola and other channels. This difference may also suggest net upwelling presence in some regions within the Indonesian seas, with the Banda Sea being one possible region (Gordon et al. 2010). The currents along these key channels were also measured, qualitatively showing that the Makassar and Timor flows are relatively constant in comparison with flows through the Lombok and Ombai passages (Gordon et al. 1999).

Focused observations of the ITF were conducted during the EWIN projects in 2013 for the Makassar Strait and in 2014 for the Maluku Sea. The observed ITF in the Makassar Strait indicated a current speed of up to $1.43 \mathrm{~ms}^{-1}$ within the thermocline at the northern part of the Makassar Strait, while it decreased at the exit of the strait to $0.9 \mathrm{~ms}^{-1}$ (Horhoruw et al. 2015). A numerical simulation for the area including the Makassar Strait by the INDESO model reproduced currents of about $1.2 \mathrm{~ms}^{-1}$ in the strait, consistent with the observed values. Results from the EWIN projects in 2014 revealed that the transport in the upper $300 \mathrm{~m}$ depth through the Maluku Sea experienced significant variability at the intraseasonal-to-interannual timescale with a magnitude of $14 \mathrm{~Sv}$. It is suggested from analyses of the observed data that this large transport variability is not associated with wind variations but related to retroflection of the Mindanao Current (Yuan et al. 2018).

While the main source of the ITF water is from the Pacific Ocean, there are also influences from the South China Sea (Qu et al. 2005, 2006; Gordon et al. 2012). For example, in the Makassar Strait route, the tropical Pacific surface water is blocked by the South China Sea surface water that passes into the Indonesian Seas through the Sibutu Passage during the El Niño period (Gordon et al. 2012). Transport through the Sibutu Passage, however, cannot compensate all the blocked Pacific surface water. Although surface layer entry to the Makassar Strait is reduced, transport in the subsurface thermocline water is increased, resulting in the cooler temperature transport of the ITF. In the La Niña period, the contribution of the South China Sea transport reduces and allows the surface water from the Pacific to enter the Makassar strait, resulting in the warmer Makassar Strait transport (Gordon et al. 2012).

\section{WATER MASS TRANSFORMATION AND UPWELLING IN THE INDONESIAN SEAS}

The three branches of the ITF inflow that gather in the Banda sea experience strong vertical mixing due to tidal mixing and associated upwelling before flowing out to the Indian Ocean, mostly through the Ombai and Timor Straits. However, a deeper part of the outflow in the Timor Strait is partly recirculated back to the Banda Sea through the Aru basin and Seram Sea (Van Bennekom 1988). The Pacific water, characterized by its high salinity maximum, no longer exists in the Banda Sea, with a reduced salinity maximum due to the intense mixing there (Koch-Larrouy et al. 2007).

The impact of tidal mixing in the Banda Sea can also be observed in the upper layer, affecting the sea surface temperature and thermocline depth, for example. Results from the joint US-Indonesian Arlindo project (1993-1994) indicate an oscillation of the thermocline layer in semidiurnal periods, suggesting influences of tidal mixing (Ffield et al. 1996). Koch-Larrouy et al. (2007) demonstrate that, using a numerical model focusing on the Indonesian Seas, a relatively large vertical diffusivity of $1.5 \mathrm{~cm}^{2} \mathrm{~s}^{-1}$ is observed along the major pathways of the ITF. They also suggest that tidal energy (40\% concentrated in Seram and Halmahera) is a major source of energy that causes strong water mass transformation along the ITF pathways. However, the influence of the tidal mixing processes on the entire ITF characteristics within this area is still not understood in detail, and more enhanced measurements and observations are necessary.

There is also evidence of vertical tidal mixing in a triangular region surrounded by the Makassar Strait, the Java Sea, and the Flores Sea. Using conductivity, temperature, and depth data obtained during the Java-Makassar-Flores cruise in August 2015, Prihatiningsih et al. (2019) demonstrated a strong vertical diffusivity of $10^{-3} \mathrm{~m}^{2} \mathrm{~s}^{-1}$. The Selayar Sea, near the exit of the Makassar Strait flow, is known to have high tidal energy (e.g. Nagai and Hibiya 2015), and the area has a relatively rough sea-bottom topography. This triangular area is located in the main route of the ITF, and the two inflows from the Makassar Strait and Java Sea intersect to generate the two outflows to the Lombok Strait and Banda Sea. The tidal vertical mixing in this region, therefore, may exert significant influences on the characteristics of the ITF water masses. Winds over the Indonesian Seas play an important role in modifying the mixing conditions of the ITF waters in the Banda Sea through changing temperature and salinity profiles by advective processes, including upwelling and downwelling. The impact of these winds

TABLE 1. Net ITF transport measured by INSTANT program for 3 years (2004-2006) in every inflow and outflow passage. Dominant ITF route is the Makassar strait, bringing an average inflow of about 11.6 Sv. Total average outflow is about 15 Sv, a bit different from total inflow. Table from Gordon et al. (2010).

\begin{tabular}{|c|c|c|c|c|c|c|}
\hline \multirow[t]{2}{*}{ Passage } & \multirow[t]{2}{*}{ Sill depth (m) } & \multirow[t]{2}{*}{ Integration range (m) } & \multicolumn{4}{|c|}{ Transport volume (Sverdrup) } \\
\hline & & & 2004 & 2005 & 2006 & Average 3 years \\
\hline Makassar & 700 & $0-2000$ & 11.3 & 11.6 & 11.8 & 11.6 \\
\hline Lifamatola & 2050 & $1250-2050$ & 2.1 & 2.6 & 2.7 & 2.5 \\
\hline Lifamatola & 2050 & $0-2050$ & 0 & 1 & 2 & 1 \\
\hline Total inflow & & & 11.6 & 13.0 & 13.4 & 12.7 \\
\hline Lombok & 300 & $0-1000$ & 2.0 & 2.3 & 3.4 & 2.6 \\
\hline Ombai & 1150 & $0-3000$ & 4.7 & 5.8 & 4.3 & 4.9 \\
\hline Timor & 1890 & $0-2000$ & 7.3 & 7.6 & 7.6 & 7.5 \\
\hline Total outflow & & & 14.0 & 15.7 & 15.3 & 15.0 \\
\hline
\end{tabular}


can be observed in various timescales, especially from seasonal to interannual variations. From April to November, the southeastern monsoonal winds prevail in driving away surface water to the west. Subsequent surface water divergence causes upwelling to occur in the Banda Sea, which leads to enrichment of nutrients in the surface layer. Northwestern winds from December to March, in contrast, generate downwelling (Wyrtki 1961; Cadée 1988). For example, the low-salinity surface water in the Arafura Sea spreads westward during the southeastern monsoon season, causing lower surface salinity and deeper mixed layer depth in the Banda Sea (Zijlstra et al. 1990). In the Banggai area of the Maluku Sea, upwelling occurs from June to October during the southeastern monsoon season, with maximum upwelling strength in September. Atmadipoera et al. (2018) investigated interannual variations of the upwelling strength in the Maluku Sea between 2008 and 2015, and found that the magnitude of upwelling in 2015 (El Niño event) was the strongest, in contrast to the 2010 upwelling (La Niña event), which was the weakest, suggesting a significant influence of ENSO on upwelling intensity.

In the Eastern Indian Ocean along the Sumatran and Javanese coasts, the southeasterly monsoon is responsible for the upwelling process in southwestern Sumatra and southern Java regions. This alongshore wind moves the region of upwelling, characterized by low SST, to the west starting from southern Nusa Tenggara to the equatorial region off western Sumatra. The upwelling is then terminated as the wind reverses. In addition to this seasonal variation associated with monsoonal winds, ENSO creates significant interannual variability of the upwelling signals in this area, due to atmospheric remote influences and the effects of the oceanic pathway from the Pacific to Indian Oceans, i.e. variability of the ITF water. During El Niño events, the ITF tends to carry colder water to southern Java, shallowing the thermocline and thus extending the area and duration of the upwelling. During La Niña events, on the other hand, because of the warmer ITF water associated with a deeper thermocline, the upwelling area shrinks alongside a shortened duration (Susanto et al. 2001).

The upwelling events and their variability can be identified based on a higher value of chlorophyll- $a$, and concurrent lower value of SST. For example, as shown by (Ratnawati et al. 2016), the chlorophyll-a concentration in southern Java during the December-February period is about $0.34 \mathrm{mg} \mathrm{m}^{-3}$, and about $0.36 \mathrm{mg} \mathrm{m}^{-3}$ during MarchMay for the northwesterly wind season and monsoon transition period. The value increases significantly during the southeastern monsoonal period, about $0.89 \mathrm{mg} \mathrm{m}^{-3}$ in June-August and $1.1 \mathrm{mg} \mathrm{m}^{-3}$ in September-November (Rat- nawati et al. 2016). The relation of chlorophyll- $a$ with upwelling parameters (Ekman pumping velocity and SST) and comparison between the Banda Sea and Indian Ocean in the south of Java are shown in Figure 2.

One of the important characteristics of the Banda Sea water is a high content of silicate in the deeper layer, which is suggested to be caused by mixing processes within the area (Van Bennekom 1988; Talley and Sprintall 2005). The silicate can be used to calculate deepwater transit times because of the linear relationship between potential temperature and silicate content below depths of 500 and $1000 \mathrm{~m}$. It was found that the water mass transit times are 2-15 years for smaller basins, 20 years for the Banda Sea and 60 years for Weber Deep (Van Bennekom 1988). In addition, the ITF water at an intermediate depth in the Indian Ocean has a high silica signature that can be traced from the Banda Sea (Talley and Sprintall 2005). Apart from the importance of this nutrient transport, estimation of the transit time enables a better understanding of bio-physical interactions and biogeochemical conditions in the Indonesian Seas and the Eastern Indian Ocean.

The mixing processes in the Indonesian Seas, along with the upwelling systems in both the Java-Sumatra regions and Indonesian Seas, still need to be discussed in more detail. Some of key questions are: what is the relation between upwelling systems and mixing processes in the Indonesian Seas, what is the role of upwelling in the freshening process of the Pacific water during its passage through the Indonesian Seas, and what is the role of downwelling in mixing and water mass transformation processes? Additionally, the relationship between upwelling intensity or mixing processes and climate variations-such as ENSO and IOD-should also be investigated in detail. In terms of biogeochemistry research in the Indonesian Sea, studies on the effect of the ITF on chlorophyll- $a$ concentrations and on overall biogeochemistry in the Banda Sea and Indian Ocean south of Java need to be enhanced.

\section{BIOGEOCHEMISTRY OF THE INDONESIAN THROUGHFLOW}

Processes of chemical materials that connect elements of the biosphere and geosphere, known as the biogeochemical cycle, influence many aspects of Earth systems, from food web structures to global climate conditions. Considering the important role of the ITF in modifying characteristics of Earth systems, such as heat transport and water mass properties, one should also take into account the significant role of the ITF on the global biogeochemical cycle. This role, however, is relatively unknown.
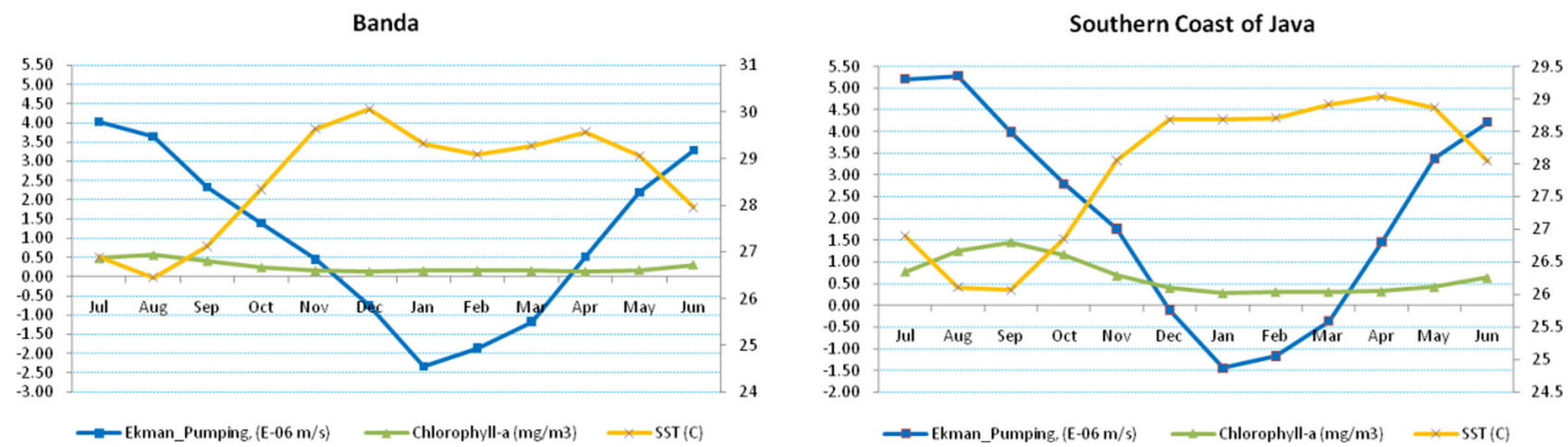

FIGURE 2. Ekman pumping, chlorophyll-a concentration, and SST variability in the Banda Sea and Southern Java. Upwelling in the Southern Javanese part of the Indian Ocean, as well as the Banda Sea, occurs during southeastern monsoons. Figure from Ratnawati et al. (2016). 
Research on the biological and chemical process inside the ITF area is usually conducted separately with different goals. For example, carbon flows in the euphotic upper layer of the Banda Sea, observed over two monsoon seasons, show that the particulate organic carbon values in this layer (from the surface to a $100 \mathrm{~m}$ depth) for the upwelling season are 1.5 times higher than those in the downwelling season. Meanwhile, contrarily, dissolved organic carbon values during the downwelling season are two times higher than those in the upwelling season (Cadée 1988). Research in the Halmahera and Maluku Seas revealed the relation of nutrient types in water with abundance of certain phytoplankton genera (Meirinawati and Fitriya 2018). Phytoplankton abundance in the Lembeh Strait differs seasonally due to monsoons. A high nutrient supply during the upwelling season drives an increase in phytoplankton abundance, while in April and October the abundance is lowered because of the monsoon transition (Tang et al. 2018).

The findings of Meirinawati and Fitriya (2018) and Tang et al. (2018) on the relationship between phytoplankton type and abundance and nutrient supply in the HalmaheraMolucca Sea and the Lembeh Strait, respectively, suggest a strong association with ITF characteristics; in other words, ocean mixing processes occur there. The questions that can be raised here, for example, are: what is the dominant nutrient type transported by the ITF, what is the effect of different compositions of phytoplankton on the primary productivity and biological pump in the Indonesian Seas and Indian Ocean in terms of the influence of ITF water, and how does the periodicity in currents and tidal waves affect nutrient and microorganism abundance?

Ayers et al. (2014) were the first to determine temporal variations in the vertical profiles of nitrate, phosphate, and silicate flux at the ITF exit passages. By counting the flux from the passages and flux of existing nutrients in the basins, they found the effective flux of nutrients transported by the ITF to the Indian Ocean (Figure 3). This effective flux reflects the level of ITF net contribution to the Indian Ocean's nutrient content. The effective fluxes are the largest in the layer from the surface to a depth of $\sim 400 \mathrm{~m}$, suggesting that the ITF enriches thermocline nutrients in the Indian Ocean (Ayers et al. 2014). Wahyudi et al. (2017) further found that in the zone affected by the South Java Current (SJC) and Southern Equatorial Counter Current (SECC), there is a distinct profile of organic matter and nutrients. In the area of SECC regulated water, particulate organic carbon and nitrogen and total suspended solid values are higher than in the SJC regulated zone. Although this finding was not directly related to the ITF itself, the SJC and SECC are Indian Ocean currents connected to the ITF.

The findings of Ayers et al. (2014) suggest that biogeochemical conditions of the Indian Ocean are influenced significantly by the uniquely strong current through the Indonesian Seas, namely the ITF. Furthermore, Wahyudi et al. (2017) confirm the relationship between physical conditions of the ocean (e.g. currents) and chemical properties of the ocean near the Indonesian Seas. These two studies take the initiative in conducting research on the roles played by the ITF in the biogeochemical processes of the Indonesian seas and the Indian Ocean.

While continuing studies on ITF physical properties per se, it is also time to advance studies of other frontier aspects, especially in biogeochemistry and its relation to the physical properties. Some research plans have actually added biogeochemistry issues for future studies. For example, Integrated Marine Biogeochemistry and Ecosys- tem Research (IMBER) is highlighting the major challenges in biogeochemistry studies, such as understanding how the seawater transformation and elements transport involved in the biogeochemical cycle relates to food web dynamics; and responses of marine biogeochemical cycles and ecosystem to the global changes (Hofmann et al. 2016). The Research Center for Oceanography of the Indonesian Institute of Sciences (RCO LIPI) has added biological shifting and dynamics of biogeochemistry for future research topics and has underlined their importance and need to be developed further (Ariana et al. 2017).

With the importance of the ITF in the world of oceanography and the many research opportunities and challenges in biogeochemistry in mind, here we list key topics that have to be tackled in future research:

1. Monitoring nutrient fluxes associated with the ITF in and out of the Indonesian Seas with their variability. The nutrient measurements on the ITF gateways (such as the Makassar Strait, the Maluku and Halmahera Seas, and the Timor, Ombai and Lombok Straits).

2. Chlorophyll- $a$, SST, and SSS, as well as tides, variability in several key upwelling/downwelling areas on the ITF pathway, and the relation of these variabilities
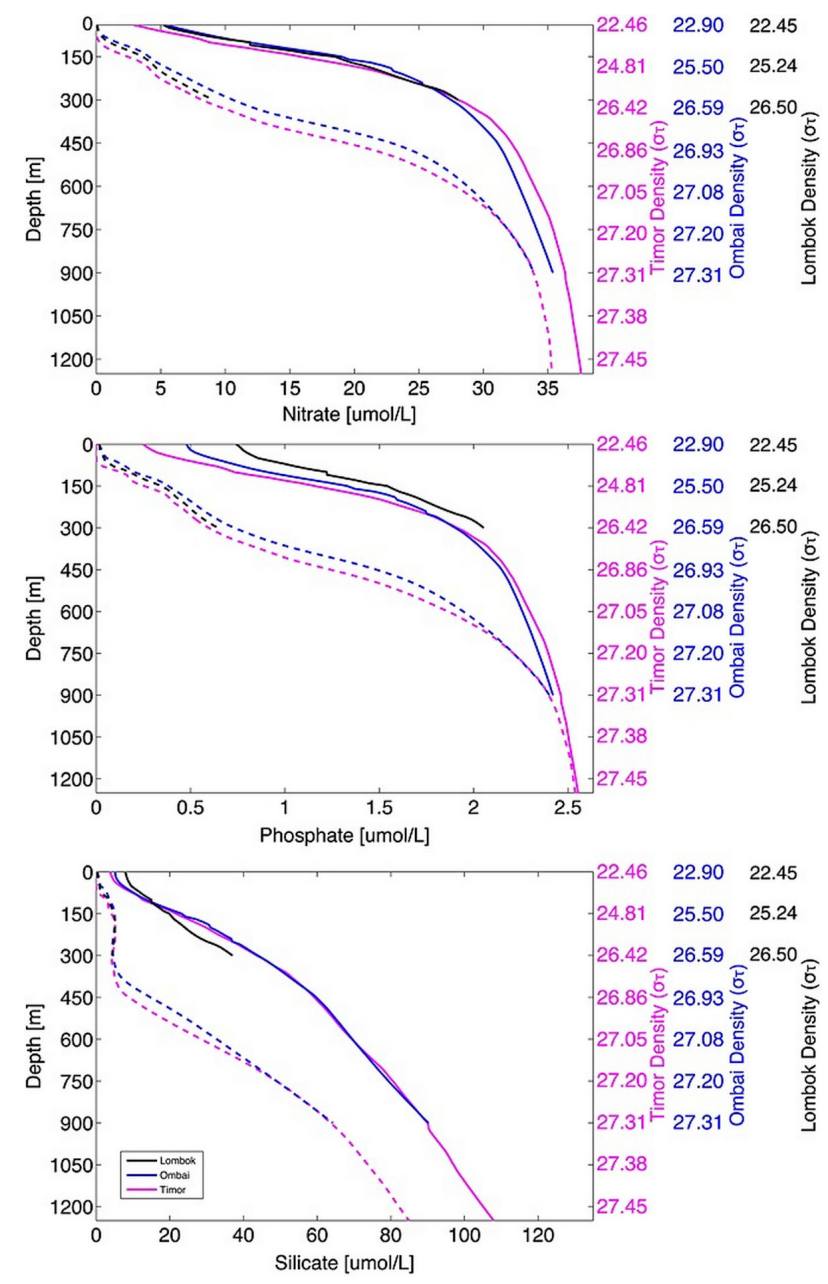

FIGURE 3. Mean nitrate (top), phosphate (middle) and silicate (down) concentration in the Lombok Strait (black), Ombai Strait (cyan) and Timor Passage (magenta). The dotted lines indicate background Indian ocean contents. Note that for nitrate and phosphate below a $\sim 900 \mathrm{~m}$ depth, the content is the same for the ITF and Indian ocean, indicating that the effective flux input from the ITF to the Indian ocean only occurs from surface to $900 \mathrm{~m}$ waters. For silicate, however, there is input for any depth. Figure from Ayers et al. (2014). 
with the ITF transport variability.

3. Characteristics and variability of the biological pump, which is related to the vertical fluxes of organic matter in the water column, in the upwelling areas along the ITF pathways.

4. Deep-sea and sediment analysis to elucidate the fate of the carbon flux and other substances.

5. Transport of nutrients and trace elements within the Indonesian Seas.

\section{CONCLUSION AND RECOMMENDATION}

The Indonesian Throughflow is a very interesting and important topic in the realm of oceanography, because of its role in global and regional ocean circulations and climate systems. Major research topics on the ITF, however, so far focus on its physical properties, mainly on the ITF transport and vertical mixing processes that transform the water mass characteristics within the Indonesian Seas. In contrast, the research on the biological and chemical properties of the ITF is still minor. Thus, for a better understanding of the roles of the ITF on marine biogeochemistry and the global climate system, we still need extensive studies based on observations and modeling. In this paper, we have attempted to list, as actionable recommendations, some prospective research topics. These include those on nutrient fluxes, the variability of chlorophyll- $a$ and primary productivity, biological pump, the fate of organic material through deep-sea sediment, and transport of nutrient and trace elements.

\section{ACKNOWLEDGMENTS}

Many thanks to Mr. Afdal for some suggestions and recommendations. Also to our colleagues of early career scientists (CPNS P2O LIPI 2019) for their meaningful support. This review paper is a contribution to the LIPI-JSPS Joint Research Project fiscal year 2020.

\section{AUTHORS' CONTRIBUTIONS}

ET as the primary contributor designed and wrote the first draft of the manuscript. AJW and ET contributed to the biogeochemistry part, YM contributed to the physical oceanography part. All authors provided works of literature, conducted manuscript proofreading, and approved the final version of the manuscript.

\section{COMPETING INTERESTS}

The authors declare no competing interest.

\section{REFERENCES}

Ariana L, Ikbal M, Alamsyah P, Nadhiroh IM, Hardiyati R, Laksani CS, Handoyo S, Zulhamdani M. 2017. Foresight riset kelautan 2020-2035 [Marine research foresight 2020-2035]. Jakarta: Research Center for Oceanography, Indonesian Institute of Sciences.

Atmadipoera AS, Khairunnisa Z, Kusuma DW. 2018. Upwelling characteristics during El Nino 2015 in Maluku Sea. IOP Conf Ser: Earth Environ Sci. 176:012018. doi: 10.1088/1755-1315/176/1/012018.

Ayers JM, Strutton PG, Coles VJ, Hood RR, Matear RJ. 2014. Indonesian throughflow nutrient fluxes and their potential impact on Indian Ocean productivity. Geophys Res Lett. 41(14):5060-5067. doi:10.1002/2014GL0605 93.
Cadée GC. 1988. Organic carbon in the upper $100 \mathrm{~m}$ and downward flux in the Banda Sea; monsoonal differences. Neth J Sea Res. 22(2):109-121. doi:10.1016/00 77-7579(88)90015-4.

Feng M, Zhang N, Liu Q, Wijffels S. 2018. The Indonesian throughflow, its variability and centennial change. Geosci Lett. 5(1):3. doi:10.1186/s40562-018-0102-2.

Ffield A, Gordon AL, Ffield A, Gordon AL. 1996. Tidal mixing signatures in the Indonesian Seas. J Phys Oceanogr. 26(9):1924-1937. doi:10.1175/1520-0485(1996)026<1924: TMSITI > 2.0.CO;2.

Godfrey JS. 1996. The effect of the Indonesian throughflow on ocean circulation and heat exchange with the atmosphere: a review. J Geophys Res Oceans. 101(C5):1221712237. doi:10.1029/95JC03860.

Gordon A. 2005. Oceanography of the Indonesian Seas. Oceanography. 18(4):13-13. doi:10.5670/oceanog.20 05.18.

Gordon AL, Huber BA, Metzger EJ, Susanto RD, Hurlburt HE, Adi TR. 2012. South China Sea throughflow impact on the Indonesian throughflow. Geophys Res Lett. 39(11). doi:10.1029/2012GL052021.

Gordon AL, Sprintall J, Van Aken HM, Susanto RD, Wijffels S, Molcard R, Ffield A, Pranowo W, Wirasantosa S. 2010. The Indonesian throughflow during 2004-2006 as observed by the INSTANT program. Dynam Atmos Ocean. 50(2):115-128. doi:10.1016/j.dynatmoce.2009.12.002.

Gordon AL, Susanto RD, Ffield A. 1999. Throughflow within Makassar Strait. Geophys Res Lett. 26(21):3325-3328. doi:10.1029/1999GL002340.

Hirst AC, Godfrey JS, Hirst AC, Godfrey JS. 1993. The role of Indonesian throughflow in a global ocean GCM. J Phys Oceanogr. 23(6):1057-1086. doi:10.1175/1520-0485(19 93) $023<1057$ :TROITI $>2.0 . \mathrm{CO} ; 2$.

Hofmann E, Allison EH, Aristegui J, Avril B, Bopp L, Bundy A, Campagna C, Chuenpagdee R, Costa D, Drinkwater KF, Gattuso JP, Glaser M, Hall J, Hobday A, Hood R, Liu KK, Liu SM, Maddison L, Maury O, Murphy E, Ogawa H, Oschlies A, Perry I, Piola A, Robinson C, Rynearson T, Sundby S, Svendsen E, Tarling G, van Putten I, Werner F, Xu Y, Yoo S, Zhang J. 2016. IMBeR 2016-2025: science plan and implementation strategy. Bergen: IMBeR International Project Office. http://www.imber.info/r esources/images/prosjekter/imber/IMBeR-Science -Plan-and-Implementation-Strategy-2017.pdf.

Horhoruw SM, Atmadipoera AS, Purba M, Purwandana A. 2015. Current structure and spatial variation of Indonesian throughflow in Makassar Strait under Ewin 2013 (Struktur arus dan variasi spasial Arlindo di Selat Makassar dari Ewin 2013). Ilmu Kelautan: Indones J Mar Sci. 20(2):87-100. doi:10.14710/ik.ijms.20.2.87-100.

Iskandar I. 2005. Intraseasonal Kelvin waves along the southern coast of Sumatra and Java. J Geophys Res Oceans. 110(C4):C04013. doi:10.1029/2004JC002508.

Koch-Larrouy A, Madec G, Bouruet-Aubertot P, Gerkema T, Bessières L, Molcard R. 2007. On the transformation of Pacific water into Indonesian throughflow water by internal tidal mixing. Geophys Res Lett. 34(4):L04604. doi:10.1029/2006GL028405.

Koch-Larrouy A, Madec G, Iudicone D, Atmadipoera A, Molcard R. 2008. Physical processes contributing to the water mass transformation of the Indonesian throughflow. Ocean Dyn. 58(3-4):275-288. doi:10.1007/s10236 -008-0154-5.

Mayer B, Damm PE, Pohlmann T, Rizal S. 2010. What is driving the ITF? An illumination of the Indonesian through- 
flow with a numerical nested model system. Dynam Atmos Ocean. 50(2):301-312. doi:10.1016/j.dynatmoce. 2010.03.002.

Meirinawati H, Fitriya N. 2018. Pengaruh konsentrasi nutrien terhadap kelimpahan fitoplankton di perairan Halmahera-Maluku [Effect of nutrient concentration on phytoplankton abundance in Halmahera-Maluku waters]. Oseanologi dan Limnologi di Indonesia. 3(3):183. doi:10.14203/oldi.2018.v3i3.129.

Murty SA, Goodkin NF, Wiguna AA, Gordon AL. 2018. Variability in coral-reconstructed sea surface salinity between the northern and southern Lombok Strait linked to East Asian winter monsoon mean state reversals. Paleoceanogr Paleoclimatol. 33(10):1116-1133. doi:10.1029/ 2018 PA003387.

Nagai T, Hibiya T. 2015. Internal tides and associated vertical mixing in the Indonesian Archipelago. J Geophys Res: Oceans. 120(5):3373-3390. doi:10.1002/2014JC01 0592.

Nugroho D, Koch-Larrouy A, Gaspar P, Lyard F, Reffray G, Tranchant B. 2018. Modelling explicit tides in the Indonesian seas: an important process for surface sea water properties. Mar Pollut Bull. 131:7-18. doi:10.101 6/j.marpolbul.2017.06.033.

Potemra J. 2005. Indonesian throughflow transport variability estimated from satellite altimetry. Oceanography. 18(4):98-107. doi:10.5670/oceanog.2005.10.

Prihatiningsih I, Jaya I, Atmadipoera AS, Zuraida R. 2019. Turbulent mixing of water masses in Selayar Slope Southern Makassar Strait. IOP Conf Ser: Earth Environ Sci. 284:012033. doi:10.1088/1755-1315/284/1/012033.

Qu T, Du Y, Meyers G, Ishida A, Wang D. 2005. Connecting the tropical Pacific with Indian Ocean through South China Sea. Geophys Res Lett. 32(24):L24609. doi:10.102 9/2005GL024698.

Qu T, Du Y, Sasaki H. 2006. South China Sea throughflow: a heat and freshwater conveyor. Geophys Res Lett. 33(23):L23617. doi:10.1029/2006GL028350.

Ratnawati HI, Hidayat R, Bey A, June T. 2016. Upwelling di Laut Banda dan Pesisir Selatan Jawa serta hubungannya dengan ENSO dan IOD [Upwelling in the Banda Sea and South Java Coast and its relationship with ENSO and IOD]. Omni-Akuatika. 12(3):119-130. doi:10.20884/1.oa. 2016.12.3.134.

Sasaki H, Kida S, Furue R, Nonaka M, Masumoto Y. 2018. An increase of the Indonesian throughflow by internal tidal mixing in a high-resolution quasi-global ocean simulation. Geophys Res Lett. 45(16):8416-8424. doi: 10.1029/2018GL078040.

Schiller A, Godfrey JS, McIntosh PC, Meyers G, Wijffels SE. 1998. Seasonal near-surface dynamics and thermodynamics of the Indian Ocean and Indonesian throughflow in a global ocean general circulation model. J Phys Oceanogr. 28(11):2288-2312. doi:10.1175/1520-0485(19 98) $028<2288$ :SNSDAT $>2.0$.CO;2.

Song Q, Vecchi GA, Rosati AJ. 2007. The role of the Indonesian throughflow in the Indo-Pacific climate variability in the GFDL coupled climate model. J Clim. 20(11):24342451. doi:10.1175/JCLI4133.1.

Sprintall J, Gordon AL, Koch-Larrouy A, Lee T, Potemra JT, Pujiana K, Wijffels SE. 2014. The Indonesian seas and their role in the coupled ocean-climate system. Nat Geosci. 7(7):487-492. doi:10.1038/ngeo2188.

Sprintall J, Gordon AL, Wijffels SE, Feng M, Hu S, KochLarrouy A, Phillips H, Nugroho D, Napitu A, Pujiana K, Dwi Susanto R, Sloyan B, Yuan D, Riama NF, Siswanto S, Kuswardani A, Arifin Z, Wahyudi AJ, Zhou H, Nagai T, Ansong JK, Bourdalle-Badié R, Chanut J, Lyard F, Arbic BK, Ramdhani A, Setiawan A. 2019. Detecting change in the Indonesian seas. Front Mar Sci. 6:257. doi:10.3389/fmars.2019.00257.

Sprintall J, Wijffels S, Gordon AL, Ffield A, Molcard R, Susanto RD, Soesilo I, Sopaheluwakan J, Surachman Y, van Aken HM. 2004. INSTANT: a new international array to measure the Indonesian throughflow. EOS. 85(39):369. doi:10.1029/2004EO390002.

Susanto RD, Gordon AL, Zheng Q. 2001. Upwelling along the coasts of Java and Sumatra and its relation to ENSO. Geophys Res Lett. 28(8):1599-1602. doi:10.1029/2000 GL011844.

Talley LD, Sprintall J. 2005. Deep expression of the Indonesian Throughflow: Indonesian intermediate water in the south equatorial current. J Geophys Res Oceans. 110(C10):C10009. doi:10.1029/2004JC002826.

Tang S, Rachman A, Fitria N, Thoha H, Chen B. 2018. Phytoplankton changes during SE monsoonal period in the Lembeh Strait of North Sulawesi, Indonesia, from 2012 to 2015. Acta Oceanol Sin. 37(12):9-17. doi:10.1007/s131 31-018-1283-4.

Van Bennekom AJ. 1988. Deep-water transit times in the eastern Indonesian basins, calculated from dissolved silica in deep and interstitial waters. Neth J Sea Res. 22(4):341-354. doi:10.1016/0077-7579(88)90004-X.

Wahyudi AJ, Iskandar MR, Meirinawati H, Afdal, Vimono IB, Afianti NF, Sianturi OR, Wirawati I, Darmayati Y, Helfinalis, Sidabutar T. 2017. Organic matter and nutrient profile of the two-current-regulated-zone in the Southwestern Sumatran Waters (SSW). Mar Res Indones. 42(1):19-33. doi:10.14203/mri.v42i1.124.

Wyrtki K. 1961. Physical oceanography of the Southeast Asian waters. La Jolla: University of California, Scripps Institution of Oceanography. https://escholarship.o rg/content/qt49n9x3t4/qt49n9x3t4.pdf.

Wyrtki K. 1987. Indonesian through flow and the associated pressure gradient. J Geophys Res Oceans. 92(C12):12941-12946. doi:10.1029/jc092ic12p12941.

Yuan D, Li X, Wang Z, Li Y, Wang J, Yang Y, Hu X, Tan S, Zhou H, Wardana AK, Surinati D, Purwandana A, Azis Ismail MF, Avianto P, Dirhamsyah D, Arifin Z, von Storch JS. 2018. Observed transport variations in the Maluku Channel of the Indonesian Seas associated with western boundary current changes. J Phys Oceanogr. 48(8):1803-1813. doi:10.1175/JPO-D-17-0120.1. http:// journals.ametsoc.org/doi/10.1175/JPO-D-17-0120.1.

Zijlstra JJ, Baars MA, Tijssen SB, Wetsteyn FJ, Witte JI, Ilahude AG, Hadikusumah. 1990. Monsoonal effects on the hydrography of the upper waters $(<300 \mathrm{M})$ of the eastern Banda Sea and northern Arafura Sea, with special reference to vertical transport processes. Neth J Sea Res. 25(4):431-447. doi:10.1016/0077-7579(90)900 68-R. 